\title{
PENGARUH TINGKAT PERTUMBUHAN PERUSAHAAN, RETURN ON ASSETS (ROA) DAN SHAREHOLDER DISPERSION TERHADAP KEBIJAKAN DEVIDEN PADA INDUSTRI MANUFAKTUR DI BURSA EFEK INDONESIA PERIODE 2011-2013
}

\author{
Amanda Deby Shevina \\ amandadeby09@gmail.com \\ Universitas Ahmad Dahlan \\ Tina Sulistyani \\ tina_uad@yahoo.com \\ Universitas Ahmad Dahlan
}

\begin{abstract}
ABSTRAK
This research aims to understand the influence of a variable degree growth of the company, return on assets ( ROA ) and shareholder dispersion partial evaluation and simultaneously to predict dividend policy to companies manufacturing industry which is listed on the Bursa Efek Indonesia. Tekhnik the sample collection by using purposive sampling method of sample and obtained 10 companies. The method of analysis data used a linear regression analysis worship of idols with the level of significance 0.05 .

The research results show that: ( 1 ) the rate of growth of the company have a negative influence and significant against its policies with a value of dividend $t$ count $-2,185$ and value of significance 0,038.( 2 ) ROA it has some positive effects and significant against its policies with a value of dividend t count 4,827 and value of significance 0,000 .( 3 ) shareholder dispersion have a negative influence and significant against its policies with a value of dividend t count $-3,420$ and value of significance 0,002. ( 4 ) the rate of growth of the company, return on assets ( ROA), shareholder dispersion in together influential positive and significant for policies with the value of dividend f count 16,089 significance and value 0,000 .
\end{abstract}

Keywords: The Level Of Growth Of The Company, Return on Assets, Shareholder dispersion and dividend policy.

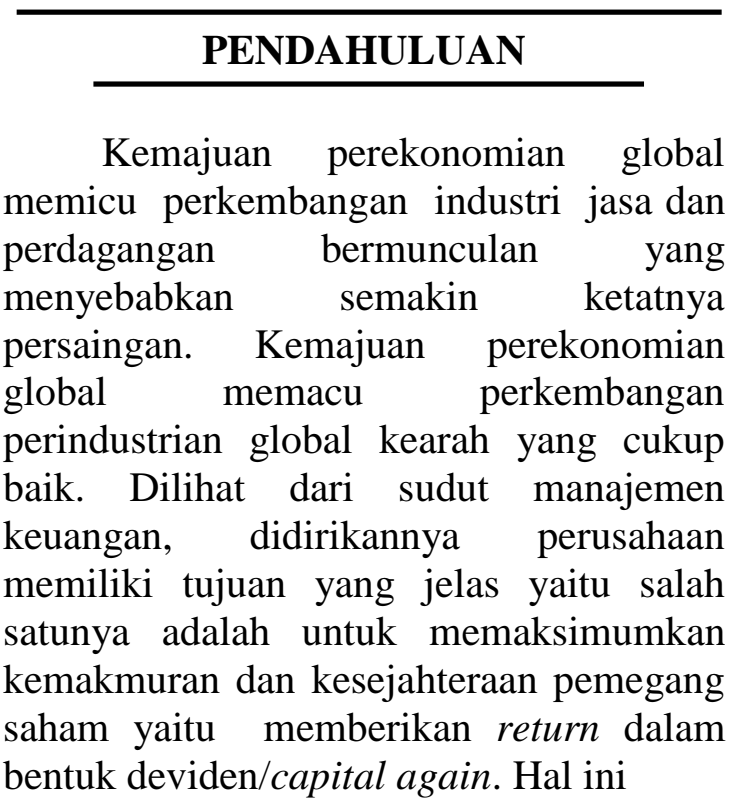

menuntut setiap perusahaan untuk melakukan efektifitas dan efisiensi agar dapat menghasilkan keuntungan untuk menutupi kebutuhan perusahaan. Efektif berkaitan dengan tujuan yang hendak dicapai, sedangkan efisien berkaitan dengan biaya yang seminimal mungkin untuk mencapai tujuan.

Pada sektor industri jasa dan perdagangan yang pesat ini ikut berperan dalam pasar modal, seperti Perusahaan Industri Manufaktur yang terdaftar di Bursa Efek Indonesia, sehingga sahamsaham yang dikeluarkan oleh perusahaan dapat dibeli oleh masyarakat yang ingin memiliki saham tersebut. 
Laba ditahan (Retained Earning) merupakan salah satu sumber dana penting untuk membiayai pertumbuhan perusahaan. Sedangkan dividen merupakan aliran kas yang dibayarkan kepada pemegang saham. Setiap perusahaan di satu pihak selalu menginginkan adanya pertumbuhan bagi perusahaan, dalam pihak perusahaan dapat membayarkan dividen kepada pemegang saham. Kedua tujuan ini saling bertentangan. Hal ini disebabkan dengan semakin tinggi tingkat dividen yang dibayarkan, maka semakin sedikit laba yang ditahan, sehingga akan menghambat tingkat pertumbuhan pendapatan dan harga saham perusahaan. Sebaliknya apabila perusahaan ingin menahan sebagian besar pendapatannya, maka semakin besar dana yang tersedia untuk ditanamkan kembali di dalam perusahaan. Hal ini akan mempercepat perumbuhan perusahaan (Asakdiyah, 2007).

Perusahaan juga mengharapkan adanya pertumbuhan (growth) secara terus menerus untuk mempertahankan kelangsungan hidupnya dan sekaligus harus dapat memberikan kesejahteraan yang lebih besar kepada para investor.Perusahaan harus menyediakan modal yang cukup agar dapat mendanai pertumbuhannya secara terus menerus untuk mempertahankan kelangsungan hidup perusahaan. Potensi pertumbuhan perusahaan menjadi faktor penting yang menentukan kebijakan dividen perusahaan. Kebijakan dividen dapat menjadi petunjuk informasi bagi para investor untuk menanamkan modalnya.

Return On Assets (ROA) yaitu salah satu rasio profitabilitas yang merupakan ukuran efektivitas perusahaan dalam menghasilkan keuntungan dengan memanfaatkan aktiva tetap yang digunakan untuk operasi. ROA merupakan perbandingan antara laba sebelum dan pajak (EBIT) dengan total aktiva yang dimiliki perusahaan. Semakin besar ROA maka berpengaruh positif terhadap perusahaan, maka menunjukan kinerja perusahaan yang semakin baik karena tingkat pengembalian investasi (return) yang semakin besar. Sebaliknya semakin kecil ROA maka berpengaruh negatif terhadap perusahaan karena menunjukkan pengembalian investasi (return) yang kecil. Menurut Sartono (2001), Return On Assets (ROA) menunjukkan kemampuan modal yang diinvestasikan dalam total aktiva untuk menghasilkan laba perusahaan. Semakin tinggi Return On Assets (ROA) maka kemungkinan pembagian dividen juga semakin banyak.

Shareholder dispersion, yaitu penyebaran pemegang saham yang berperan didalam masalah keagenan. Semakin banyak pemegang saham yang menyebar mengakibatkan pemegang saham sulit mengontrol manajemennya terhadap perusahaan. Semakin menyebar pemilik saham mengakibatkan jumlah dividen yang di bagikan semakin besar. Konsekuensi dari penyebaran pemegang saham ini adalah dengan membagikan dividen yang besar untuk mengurangi konflik keagenan.

Perusahaan yang membagikan dividen lebih tinggi cenderung lebih dapat mengurangi konflik keagenan mereka daripada perusahaan yang membagikan dividennya lebih rendah.Perusahaan yang keuntungannya relatif teratur seringkali dapat memperkirakan bagaimana keuntungan dikemudian hari. Maka perusahaan seperti itu kemungkinan besar akan membagikan keuntungannya dalam bentuk dividen dengan presentase yang lebih besar dibandingkan dengan perusahaan yang keuntungannya berfluktuatif (Sundjaja, 2002).

Laba merupakan hal utama yang penting bagi perusahaan maupun investor, dimana sebagai kepentingan perusahaan untuk menjaga kelangsungan hidup perusahaan. Perusahaan berkepentingan untuk meningkatkan pertumbuhan perusahaan dimana tetap bisa memenuhi kebutuhan dana namun di pihak lain juga harus memenuhi investor dalam pembagian laba yang diperoleh (dividen) 
sehingga investor tidak mengalihkan investasinya ke perusahaan lain.

Kebijakan dividen menjadi hal yang menarik karena merupakan harapan investor tetapi disisi lain kebijakan tersebut jangan sampai menghambat pertumbuhan perusahaan terutama mengancam kelangsungan hidup perusahaan. Dalam penelitian ini variabel yang mempengaruhi kebijakan dividen adalah tingkat pertumbuhan perusahaan, ROA dan shareholder dispersion.

Tujuan dari penelitian ini di antaranya: 1) untuk mengetahui pengaruh Tingkat Pertumbuhan Perusahaan terhadap kebijakan dividen pada perusahaan industri manufaktur yang terdaftar di BEI pada periode tahun 20112013, 2) untuk mengetahui pengaruh Return On Assets terhadap kebijakan dividen pada perusahaan industri manufaktur yang terdaftar di BEI pada periode tahun 2011-2013, 3) untuk mengetahui pengaruh Shareholder Dispersion terhadap kebijakan dividen pada perusahaan industri manufaktur yang terdaftar di BEI pada periode tahun 20112013 dan 4) untuk mengetahui pengaruh Tingkat Pertumbuhan Perusahaan, Return On Assets dan Shareholder Dispersion terhadap kebijakan dividen secara simultan pada perusahaan industri manufaktur yang terdaftar di BEI pada periode tahun 20112013.

\section{REVIEW LITERATUR DAN HIPOTESIS}

\section{Landasan Teori}

\section{Pasar Modal}

Menurut Tandelilin (2010) Pasar Modal adalah pertemuan antara pihak yang memiliki kelebihan dana dengan pihak yang membutuhkan dana dengan cara memperjualbelikan sekuritas. Dengan demikian, pasar modal juga bisa diartikan sebagai pasar untuk memperjualbelikan sekuritas yang umumnya memiliki umur lebih dari satu tahun, seperti saham dan obligasi.
2. Deviden

Menurut Awat (1999) Dividen adalah bagian dari laba bersih yang dibagikan kepada para pemegang saham (pemilik modal sendiri).

3. Kebijakan Deviden

Kebijakan dividen adalah keputusan apakah laba yang diperoleh perusahaan akan diberikan kepada pemegang saham sebagai dividen atau akan ditahan dalam bentuk laba ditahan guna pembiayaan investasi dimasa datang (Sartono, 2001).

\section{Tingkat Pertumbuhan Perusahaan}

Menurut Sartono (2001) semakin cepat pertumbuhan perusahaan maka semakin besar kebutuhan dana untuk pembiayaan mendatang maka semakin besar keinginan perusahaan untuk menahan laba. Jadi perusahaan yang sedang tumbuh sebaiknya tidak membagikan laba sebagai dividen tetapi lebih baik digunakan untuk pembiayaan investasi. Potensi pertumbuhan ini dapat diukur dari besarnya biaya penelitian dan pengembangan. Semakin besar R \& D cost-nya maka berarti ada prospek perusahaan untuk tumbuh.

Tingkat pertumbuhan perusahaan berpengaruh terhadap kebijakan dividen karena semakin cepat tingkat pertumbuhan suatu perusahaan, maka semakin besar kebutuhan dana yang diperlukan untuk membiayai pertumbuhan tersebut. Semakin besar kebutuhan dana untuk waktu mendatang, maka perusahaan lebih senang untuk menahan labanya daripada membayarkannya sebagai dividen kepada para pemegang saham.

\section{Return On Asset}

$$
\text { Return On Assets (ROA) }
$$

mengukur kemampuan perusahaan dalam memanfaatkan aktivanya untuk memperoleh laba. Rasio ini mengukur tingkat kembalian investasi yang telah 
dilakukan oleh perusahaan dengan menggunakan seluruh dana (aktiva) yang dimilikinya. Ratio ini dapat diperbandingkan dengan tingkat bunga bank yang berlaku (Prastowo, 2011).

ROA merupakan rasio profitabilitas yang berpengaruh positif terhadap kebijakan dividen karena dividen sebagian dari laba bersih yang diperoleh perusahaan, oleh karena itu dividen akan dibagikan apabila perusahaan memperoleh keuntungan. Perusahaan yang semakin besar keuntungannya diharapkan akan membayar dividen yang lebih tinggi kepada para pemegang saham.

\section{Shareholder Dispersion}

Shareholder

dispersion

merupakan penyebaran pemilik saham yang dikarenakan para investor terlalu berani mengambil risiko sehingga terjadi kesulitan pada para investor dalam mengontrol manajemennya. Para manajer dalam menjalankan operasi perusahaan, seringkali tergoda untuk meningkatkan kesejahteraan sendiri dibandingkan memaksimumkan kemakmuran shareholder dispersion. Shareholder dispersion berpengaruh terhadap kebijakan dividen karena ketika kepemilikan saham menyebar, maka menimbulkan konflik keagenan. Para pemilik saham memiliki kekuatan untuk menyampaikan harapannya kepada manajemen. Untuk mengurangi konflik keagenan tersebut manajemen akan memberikan dividen yang besar.

\section{Penelitian Terdahulu}

1. Dalam penelitian Prasetia (2010), yang meneliti dengan judul "Pengaruh Return On Assets, Shareholder Dispersion dan Tingkat Pertumbuhan Perusahaan Terhadap Kebijakan Dividen pada Perusahaan Food and Baverage yang terdaftar di Bursa Efek Indonesia periode 2004-2008.
Populasi dalam penelitian ini adalah seluruh perusahaan food and baverage yang terdaftar di Bursa Efek Indonesia periode 2004-2008. Pengambilan sample menggunakan teknik purposive sampling dan diperoleh 16 perusahaan. Data dikumpulkan dengan metode dokumentasi, metode analisis data sekunder menggunakan regresi linier berganda. Hasil analisis ROA berpengaruh positif dan signifikan terhadap kebijakan dividen. Hal ini ditunjukkan dengan koefisien t-hitung sebesar 8,970 dengan probabilitas tingkat kesalahan sebesar 0,000 lebih kecil dibanding tingkat signifikan yang diharapkan $(0,000<0,05)$. Shareholder dispersion berpengaruh negatif dan signifikan terhadap kebijakan dividen, hal ini ditunjukkan dengan koefisien t-hitung sebesar $-3,000$ dengan probabilitas tingkat kesalahan sebesar 0,004 lebih kecil dibanding tingkat signifikan yang diharapkan $(0,004<$ $0,05)$. Tingkat pertumbuhan perusahaan berpengaruh negatif tidak signifikan terhadap kebijakan dividen. Hal ini ditunjukkan dengan koefisien t-hitung sebesar -0,251 dengan probabilitas tingkat kesalahan sebesar 0,082 lebih besar dibanding tingkat signifikan yang diharapkan $(0,802>0,05)$. Return On Assets, Shareholder Dispersion dan Tingkat Pertumbuhan Perusahaan secara bersama-sama berpengaruh positif terhadap kebijakan dividen. Hal ini dapat dilihat dari nilai Fhitung sebesar 35,800 dengan signifikan 0,000 lebih kecil dari tingkat signifikan yang diharapkan $(0,000<$ 0,05). Persamaan Regresi ganda yang diperoleh yaitu, $\mathrm{Y}=2,306+0,611 \mathrm{ROA}-$ 0,664 Shareholder Dispersion -0,013 Tingkat Pertumbuhan Perusahaan. 
2. Dalam penelitian Rahmawati (2013) yang meneliti dengan judul Pengaruh Return On Assets, Shareholder Dispersion dan Tingkat Pertumbuhan Perusahaan Terhadap Kebijakan Deviden Pada Perusahaan Food and Baverage yang terdaftar di BEI periode tahun 2008-2010 sebanyak 10 perusahaan. Data dikumpulkan dengan metode dokumentasi, metode analisis sekunder menggunakan regresi linier berganda. Hasil analisis data Rahmawati diperoleh kesimpulan, regresi linier berganda diperoleh konstanta: $-1,205$, yang artinya apabila tidak ada pengaruh variabel bebas (Return On Assets, Shareholder Dispersion, Tingkat Pertumbuhan Perusahaan), maka besarnya $\mathrm{Y}=$ 1,205. Dari t-test diperoleh hasil bahwa secara parsial (sendiri-sendiri) variabel Return On Assets berpengaruh positif dan signifikan terhadap kebijakan dividen, dapat dilihat dari nilai t hitung sebesar 4,527 dan nilai signifikansinya yang lebih kecil dari taraf signifikan (5\%) yaitu sebesar 0,000. Sedangkan variabel Sharehoder Dispersion dan Tingkat Pertumbuhan Perusahaan tidak berpengaruh secara signifikan terhadap kebijakan dividen karena masing-masing memiliki nilai signifikansi lebih besar dari taraf signifikan $(5 \%)$ yaitu 1,000 dan 0,235. Secara simultan Return On Assets, Shareholder Dispersion dan Tingkat Pertumbuhan Perusahaan mempunyai pengaruh positif dan signifikan terhadap kebijakan dividen, hal tersebut dapat dilihat dari hasil statistik yang menunjukan nilai $\mathrm{F}$ hitung sebesar 7,352 dan nilai signifikansi yang lebih kecil dari taraf signifikan (5\%) yaitu sebesar
0,002. Koefisien determinasi atau $\mathrm{R}$ square $=56,5 \%$ artinya Return On Assets (X1), Shareholder Dispersion (X2), Tingkat Pertumbuhan Perusahaan (X3) menjelaskan variabel $\mathrm{Y}$ sebesar $56,5 \%$, sisanya diterangkan oleh variabel lain selain $\mathrm{X} 1, \mathrm{X} 2, \mathrm{X} 3$ sebesar $43,5 \%$.

\section{Hipotesis}

H1: Tingkat Pertumbuhan Perusahaan berpengaruh negatif terhadap Kebijakan Dividen Pada Industri Manufaktur yang terdaftar di BEI (2011-2013).

H2: Return On Assets berpengaruh positif terhadap Kebijakan Dividen Pada Industri Manufaktur yang terdaftar di BEI (2011-2013).

H3: Shareholder

Dispersion berpengaruh negatif terhadap Kebijakan Dividen Pada Industri Manufaktur yang terdaftar di BEI (2011-2013).

H4: Tingkat Pertumbuhan Perusahaan, ROA dan Shareholder Dispersion secara simultan berpengaruh positif terhadap Kebijakan Dividen Pada Industri Manufaktur yang terdaftar di BEI (2011-2013).

\section{METODE PENELITIAN}

\section{Populasi dan Sampel}

Populasi adalah wilayah generalisasi yang terdiri dari obyek atau subyek yang mempunyai kualitas dan karakteristik tertentu yang ditetapkan oleh peneliti untuk dipelajari dan kemudian ditarik kesimpulan (Sugiyono, 2007). Populasi dalam penelitian ini adalah seluruh Perusahaan Industri Manufaktur yang terdaftar di BEI periode 2011-2013 sebanyak 141 perusahaan. Pemilihan sampel dilakukan dengan purposive 
sampling. Purposive sampling adalah penentuan sampel dengan pertimbangan tertentu, kriteria sampel tersebut sebagai berikut:

a. Perusahaan yang diteliti adalah perusahaan industri manufaktur pada periode 2011-2013 yang listing di BEI.

b. Perusahaan Industri Manufaktur yang menerbitkan data laporan keuangan lengkap selama 3 tahun secara berturutturut dari 31 Desember 2011 - 31 Desember 2013.

c. Perusahaan yang membagikan dividen secara berturut-turut pada periode 20112013.

\section{Definisi Operasional}

1. Variabel Independen

a. Tingkat Pertumbuhan Perusahaan

Pertumbuhan perusahaan merupakan perbandingan antara penjualan tahun yang bersangkutan (tahun ke t) dikurangi dengan penjualan tahun sebelumnya (tahun t-1) kemudian dibagi dengan penjualan-penjualan tahun sebelumnya.

Growth $=\left(\frac{\text { Net Sales tahun sekarang }_{\mathrm{t}}-\text { Net Sales tahun lalu }_{\mathrm{t}-1}}{\text { Net Sales tahun lalu } \mathrm{t}-1}\right)$

b. Return On Assets

Return On Assets (ROA) dihitung berdasarkan perbandingan laba bersih setelah pajak terhadap total aktiva yang dimiliki perusahaan. Menurut Prastowo (2011) ROA dapat dihitung dengan rumus sebagai berikut:

ROA $=\frac{\text { Laba setelah pajak,tetapi sebelum bunga }}{\text { Aktiva Rata-rata }}$

c. Shareholder Dispersion

Variance $=\frac{\sum_{i=1}^{n}(x 1-\bar{x})-n}{n-1}$

$\mathrm{X} 1$ = Presentasi kepemilikan saham tiap kelompok

$\mathrm{X}=$ Rata-rata kepemilikan saham

$\mathrm{n}=$ Jumlah data
2. Variabel Dependen

Variabel terikat dalam penelitian ini adalah kebijakan dividen pada Perusahaan Industri Manufaktur yang terdaftar di Bursa Efek Indonesia. Kebijakan dividen di ukur dengan menggunakan Divident Payout Ratio (DPR). Menurut Prastowo (2011), Divident Payout Ratio mengukur proporsi laba bersih per satu lembar saham biasa yang dibayarkan dalam bentuk dividen.

$\mathrm{DPR}=\frac{\text { Dividen perlembar saham biasa }}{\text { Earning per share }}$

\section{Uji Instrumen}

1. Uji Asumsi Klasik

a. Normalitas

Uji normalitas bertujuan untuk mengetahui normal tidaknya suatu distribusi data. Pada dasarnya, uji normalitas adalah membandingkan antara data yang kita miliki dan data berdistribusi normal yang memiliki mean dan standar deviasi yang sama dengan kita. Uji normalitas menjadi hal penting karena salah satu syarat pengujian parametic test (uji parametik) adalah data harus memiliki distribusi normal (Sarjono, 2013). Kriteria pengujian:

Angka signifikansi uji KolmogorovSmirnov Sig $>\quad \alpha \quad(0,05)$, menunjukkan data berdistribusi normal.

Angka signifikansi uji KolmogorovSmirnov Sig $<\alpha \quad(0,05)$, menunjukkan data tidak berdistribusi normal.

b. Autokorelasi

Pengujian ini bertujuan menguji apakah dalam metode regresi linier ada korelasi antara kesalahan penggunaan pada periode $\mathrm{t}$ dengan kesalahan penggunaan periode $\mathrm{t}-1 \quad$ (sebelumnya). Autokorelasi merupakan korelasi 
antara anggota data runtun waktu atau antara space untuk data cross section (Sarjono, 2013). Run test sebagai bagian dari statistik nonparametik dapat digunakan untuk menguji apakah antar residual terdapat korelasi yang tinggi atau tidak. Jika antar residual tidak terdapat hubungan korelasi maka dikatakan bahwa residual adalah acak atau random. Run Test digunakan untuk melihat apakah residual terjadi secara random atau tidak. Keputusan ada tidaknya autokorelasi adalah:

Jika Asymp. sig pada output run test $>\propto 0,05$ (tidak terjadi autokorelasi)

Jika Asymp. sig pada output run test $>\alpha 0,05$ (terjadi autokorelasi)

c. Heteroskedastisitas

Pengujian ini bertujuan menguji apakah model regresi terjadi ketidaksamaan variasi dan residual satu pengamatan ke pengamatan lainnya, jika tetap maka disebut homokedastisitas, jika berbeda disebut heteroskedastisitas. Ada beberapa cara untuk mendeteksi ada tidaknya heteroskedastisitas yaitu dengan melihat scatter plot serta melalui uji gletjer, uji park dan uji white (Sarjono, 2013). Dalam penelitian ini menggunakan uji Glejser, untuk mengetahui terjadi tidaknya heteroskedastisitas dapat dilihat dari:

Jika nilai sig $>\alpha 0,05$ (tidak terjadi heteroskedastisitas)

Jika nilai sig $<\alpha 0,05$ (terjadi heteroskedastisitas)

Jika nilai tolerance $<\alpha 0,05$ (tidak terjadi heteroskedastisitas)

Jika nilai tolerance $>\alpha \quad 0,05$ (terjadi heteroskedastisitas)

d. Multikolinieritas

$$
\text { Model yang mempunyai }
$$
standard error besar dan nilai statistik $\mathrm{t}$ yang rendah, dengan demikian merupakan indikasi awal adanya masalah multikolinearitas dalam model (Widarjono, 2009).

Metode yang dapat dilakukan untuk menguji adanya multikolinearitas ini adalah dengan melihat tolerance value, yaitu berada di atas nilai 0,01 dan variance inflation factors (VIF) adalah di bawah 10 (Ghozali, 2005). Jika nilai tolerance value berada di bawah 0,01 atau nilai variance inflation factors (VIF) berada di atas 10 maka terjadi multikolinearitas.

\section{Teknik Analisis Data}

1. Analisis Regresi Berganda

Pengujian hipotesis dilakukan dengan menggunakan analisis regresi linier berganda. Regresi linier berganda digunakan untuk mengetahui ada tidaknya pengaruh variabel independen terhadap variabel dependen.

$\mathrm{Y}=\mathrm{a}+\mathrm{b} 1 \mathrm{X} 1+\mathrm{b} 2 \mathrm{X} 2+\mathrm{b} 3 \mathrm{X} 3$

Keterangan:

$\mathrm{Y}=$ Kebijakan dividen

$\mathrm{X} 1=$ Tingkat pertumbuhan

$\mathrm{X} 2=$ Return On Asets

X3 = Shareholder Dispersion

$\mathrm{a}=$ Nilai konstanta

$\mathrm{b}=$ Nilai koefisien variabel

\section{Uji Hipotesis}

\section{Uji Parsial (Uji T)}

Untuk mengetahui atau menguji apakah ada pengaruh antara masingmasing variabel independen terhadap Kebijakan Dividen secara individu.

Apabila sig hitung $>\alpha 5 \%$, maka $\mathrm{H} 0$ diterima dan Haditolak.

Apabila sig hitung $<\alpha 5 \%$ maka $\mathrm{H} 0$ ditolak dan Haditerima.

\section{Uji Simultan (Uji F)}

Pengujian ini bertujuan untuk mengetahui apakah pengaruh antara variabel tingkat pertumbuhan perusahaan, return on assets, shareholder dispersion terhadap 
kebijakan dividen secara bersama-sama pada perusahaan industri manufaktur. Apabila sig hitung $>\alpha 5 \%$ maka $\mathrm{H} 0$ diterima dan Ha ditolak.

Apabila sign hitung $<\alpha 5 \%$ maka $\mathrm{H} 0$ ditolak dan Ha diterima.

\section{Uji Koefisien Determinasi}

Pengujian ini digunakan untuk menguji seberapa besar presentase variabel independen tingkat pertumbuhan perusahaan, return on assets, shareholder dispersion terhadap variabel dependen kebijakan dividen pada perusahaan industr manufaktur yang terdaftar di Bursa Efek Indonesia. Besarnya koefisien determinasi berkisar antara 0 sampai 1. Apabila besarnya koefisien determinasi suatu persamaan mendekati nol maka semakin kecil pula pengaruh variabel independen terhadap dependen. Sebaliknya apabila koefisien determinasi semakin mendekati 1 maka semakin besar pula pengaruh variabel independen terhadap variabel dependen.

\section{HASIL PENELITIAN DAN PEMBAHASAN}

\section{Hasil Penelitian}

1. Hasil Uji Analisis Deskriptif

\begin{tabular}{|l|r|r|r|}
\hline & \multicolumn{1}{|c|}{ UJI DESKRIPTIF } \\
\hline & \multicolumn{1}{c|}{$\mathrm{N}$} & \multicolumn{1}{c|}{ Mean } & $\begin{array}{c}\text { Std. } \\
\text { Deviation }\end{array}$ \\
\hline tingkat_pertumbuhan_perusahaan & 30 & 14.2670 & 8.98419 \\
ROA & 30 & 17.1237 & 13.81941 \\
shareholder_dispersion & 30 & 85.5308 & 148.70172 \\
kebijakan_dividen & 30 & 45.2757 & 23.50939 \\
& & & \\
\hline
\end{tabular}

Berdasarkan hasil analisis statistik deskriptif pada tabel di atas, terlihat rata-rata (mean) kebijakan dividen dari perusahaan sampel selama periode 2011-2013 sebesar 45,2757 dengan standar deviasi 23,50939. Nilai standar deviasi kebijakan dividen lebih kecil dari rata-rata (mean) yang berarti mengindikasikan bahwa data variabel kebijakan dividen baik. Begitu juga yang terjadi dengan variabel tingkat pertumbuhan perusahaan dan return on asset (ROA) mempunyai nilai mean lebih besar dari standar deviasi. Variabel tingkat pertumbuhan perusahaan memiliki nilai mean 14,2670 standar deviasi 8,98419 dan variabel return on assets mempunyai nilai mean sebesar 17,1237 standar deviasi 13,81941. Sedangkan variabel shareholder dispersion mempunyai nilai mean sebesar 85,5308 standar deviasi $148,70142 \quad$ yang mengindikasikan bahwa data variabel shareholder dispersion tidak baik.

2. Hasil Uji Asumsi Klasik

a. Normalitas

\begin{tabular}{|l|r|}
\hline \multicolumn{2}{|c}{ UJI NORMALITAS } \\
\hline N & Unstandardized Residual \\
\hline Kolmogorov-Smirnov Z & 30 \\
Asymp. Sig. (2-tailed) & .584 \\
\hline
\end{tabular}

Berdasarkan hasil dari tabel di atas, dapat disimpulkan bahwa residual persamaan regresi pada penelitian ini mempunyai distribusi normal. Hal ini terlihat pada nilai signifikan kolmogorov-smirnov sebesar 0,885 yang berarti lebih besar dari taraf signifikan 0,05.

b. Autokorelasi

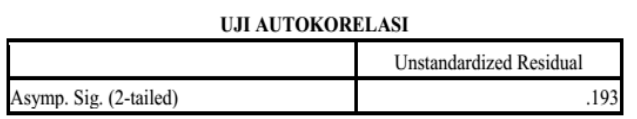

Berdasarkan hasil dari tabel di atas, dapat disimpulkan bahwa tidak terjadi autokorelasi. Hal ini dapat dilihat dari nilai signifikansi (Asymp) sebesar 0,193 yang berarti lebih besar dari taraf signifikan 0,05.

c. Heteroskedastisitas

\begin{tabular}{|l|r|r|}
\hline \multicolumn{4}{|c|}{ UJI HETEROSKEDASTISITAS } \\
\hline Model & \multicolumn{1}{c|}{ t } & \multicolumn{1}{c|}{ Sig. } \\
\hline (Constant) & 1.240 & .226 \\
TINGKAT_PERTUMBUHAN_PERUSAHAAN & .881 & .387 \\
ROA & 1.521 & .140 \\
SHAREHOLDER_DISPERSION & .395 & .696 \\
\hline
\end{tabular}


Berdasarkan hasil dari tabel di atas, dapat disimpulkan bahwa tidak terjadi heteroskedastisitas. Hal ini terlihat dari nilai signifikansi ketiga variabel di atas berturut-turut 0,387 (X1), 0,140 (X2), 0,696 (X3) yang berarti lebih besar dari taraf signifikan 0,05 .

d. Multikolinieritas

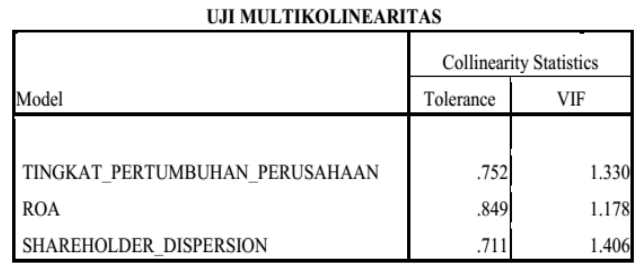

Berdasarkan hasil dari tabel di atas, dapat disimpulkan bahwa tidak terjadi multikolinearitas. Hal ini terlihat pada nilai VIF untuk ketiga variabel berturut-turut sebesar 1,330 (X1), 1,178 (X2), 1,406 (X3) yang berarti nilai VIF ketiga variabel lebih kecil dari angka 10 yang menunjukkan tidak terjadi multikolinearitas.

3. Hasil Uji Regresi Linier Berganda UJI REGRESI LINEAR BERGANDA

\begin{tabular}{|l|r|r|}
\hline \multirow{2}{*}{ Model } & \multicolumn{2}{|c|}{ Unstandardized Coefficients } \\
\cline { 2 - 3 } & \multicolumn{1}{|c|}{ B } & \multicolumn{1}{c|}{ Std. Error } \\
\hline (Constant) & 44.845 & 7.448 \\
TINGKAT_PERTUMBUHAN_PERUSAHAAN & -.765 & .350 \\
ROA & 1.034 & .214 \\
SHAREHOLDER_DISPERSION & -.074 & .022 \\
\hline
\end{tabular}

Kebijakan Dividen $=44,845-0,765$ Tingkat Pertumbuhan Perusahaan + 1,034 ROA - 0,074 Shareholder Dispersion

Dari persamaan regresi linear berganda di atas dapat dijelaskan sebagai berikut:

a. Nilai konstanta sebesar 44,845 berarti bahwa jika variabel tingkat pertumbuhan perusahaan, return on assets, shareholder dispersion adalah nol maka nilai kebijakan dividen pada perusahaan industri manufaktur akan sama dengan nilai konstanta yaitu sebesar 44,845 poin.

b. Koefisien regresi Tingkat Pertumbuhan Perusahaan (X1) sebesar $-0,765$ berarti bahwa setiap penurunan satu nilai dari tingkat pertumbuhan perusahaan maka akan memberikan kenaikan kebijakan dividen pada perusahaan industri manufaktur sebesar 0,765 poin. Sebaliknya setiap kenaikan satu nilai dari tingkat pertumbuhan perusahaan maka akan memberikan penurunan kebijakan dividen pada perusahaan industri manufaktur sebesar 0,765 poin.

c. Koefisien regresi ROA (X2) sebesar 1,304 , berarti bahwa setiap kenaikan satu nilai dari ROA maka akan memberikan kenaikan kebijakan dividen pada perusahaan industri manufaktur sebesar 1,304 poin. Sebaliknya setiap penurunan satu nilai dari ROA maka akan memberikan penurunan kebijakan dividen pada perusahaan industri manufaktur sebesar 1,304 poin.

d. Koefisien regresi Shareholder Dispersion (X3) sebesar -0,074, berarti bahwa setiap penurunan satu nilai dari shareholder dispersion maka akan memberikan kenaikan kebijakan dividen pada perusahaan industri manufaktur sebesar 0,074 poin. Sebaliknya setiap kenaikan satu nilai dari shareholder dispersion maka akan memberikan penurunan kebijakan dividen pada perusahaan industri manufaktur sebesar 0,074 poin.

\section{Hasil Uji Parsial (Uji T)}

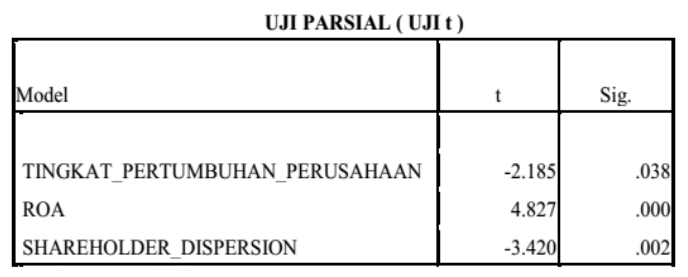

Dengan melihat hasil uji statistik t pada tabel di atas, maka pengaruh variabel-variabel independen terhadap variabel dependen dapat dijelaskan sebagai berikut: 
a. Pengujian secara parsial terhadap variabel Tingkat Pertumbuhan Perusahaan. Dari tabel dapat dilihat bahwa nilai signifikan dihitung sebesar 0,038. Karena angka tersebut lebih kecil dari angka signifikan 0,05 yang merupakan taraf signifikan, maka Ho1 ditolak dan Hal diterima atau dapat disimpulkan bahwa terdapat pengaruh yang signifikan dari tingkat pertumbuhan perusahaan terhadap kebijakan dividen.

b. Pengujian secara parsial terhadap variabel return on assets (ROA). Dari tabel dapat dilihat bahwa nilai signifikan hitung sebesar 0,000 . Karena angka tersebut lebih kecil dari angka signifikan 0,05 yang merupakan taraf signifikan, maka Ho2 ditolak atau Ha2 diterima atau dapat disimpulkan bahwa ada pengaruh yang signifikan dari return on assets terhadap kebijakan dividen.

c. Pengujian secara parsial terhadap variabel Shareholder Dispersion. Dari tabel dapat dilihat bahwa nilai signifikan hitung sebesar 0,002. Karena angka tersebut lebih kecil dari angka signifikan 0,05 yang merupakan taraf signifikan, maka Ho3 ditolak atau Ha3 diterima atau dapat disimpulkan bahwa ada pengaruh yang signifikan dari shareholder dispersion terhadap kebijakan dividen.

\section{Hasil Uji Simultan (Uji F)}

UJI SIMULTAN ( UJI F )

\begin{tabular}{|c|c|c|}
\hline Model & F & Sig. \\
\hline Regression & 16.089 & $.000^{\mathrm{a}}$ \\
\hline
\end{tabular}

mengetahui apakah variabel-variabel independen secara bersama-sama mempunyai pengaruh signifikan terhadap variabel dependen. Dari hasil analisis regresi pada tabel di atas dapat diketahui bahwa secara bersama-sama variabel independen memiliki pengaruh yang signifikan terhadap variabel dependen. Hal ini dapat dibuktikan dari nilai $\mathrm{F}$ hitung sebesar 16,089 dengan nilai signifikansi 0,000 . Karena nilai signifikansi jauh lebih kecil dari taraf tingkat signifikansi yang digunakan yaitu 0,05 (5\%), maka H04 ditolak atau Ha4 diterima atau dapat dikatakan bahwa variabel yang meliputi tingkat pertumbuhan perusahaan, ROA, shareholder dispersion secara bersama-sama berpengaruh signifikan terhadap kebijakan dividen.

\section{Hasil Uji Koefisien Determinasi}

$$
\text { Uji R-SQUARE }
$$

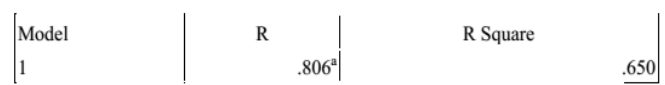

Koefisien determinasi ( $\mathrm{R}$ square) digunakan untuk menguji seberapa besar presentase variabel independen tingkat pertumbuhan perusahaan, return on assets, shareholder dispersion terhadap variabel dependen kebijakan dividen pada perusahaan industri manufaktur yang terdaftar di Bursa Efek Indonesia. Besarnya koefisien determinasi berkisar antara 0 sampai 1 . Apabila besarnya koefisien determinasi suatu persamaan mendekati nol maka semakin kecil pula pengaruh variabel independen terhadap dependen. Sebaliknya apabila koefisien determinasi semakin mendekati 1 maka semakin besar pula pengaruh variabel independen terhadap variabel dependen. Berdasarkan hasil output SPSS 17.0 pada tabel di atas tampak bahwa dari hasil perhitungan diperoleh nilai koefisien determinasi (R2) pada perusahaan industri manufaktur yang terdaftar di Bursa Efek Indonesia periode 2011-2013 sebesar 0,650. Hal ini menunjukkan bahwa variabel 
independen Tingkat Pertumbuhan Perusahaan, ROA, Shareholder Dispersion mampu menjelaskan perubahan variabel dependen yaitu Kebijakan Dividen sebesar $65 \%$ sedangkan sisanya 35\% dijelaskan oleh variabel lain di luar variabel yang digunakan dalam penelitian ini.

\section{Pembahasan}

1. Analisis pengaruh Tingkat Pertumbuhan Perusahaan, Return On Assets dan Shareholder Dispersion secara parsial terhadap kebijakan dividen.

a. Analisis pengaruh Tingkat Pertumbuhan Perusahaan (Growth) terhadap Kebijakan Dividen.

Dari uji parsial (uji t) diperoleh hasil bahwa variabel Tingkat Pertumbuhan Perusahaan (Growth) berpengaruh negatif dan signifikan terhadap kebijakan dividen. Hal ini ditunjukkan dengan koefisien t-hitung sebesar -2,185 dengan nilai signifikansi sebesar 0,038 lebih kecil dibanding dengan taraf tingkat signifikan yang diharapkan yaitu $5 \%(0,038<0,05)$. Hasil tersebut sesuai dengan teori dari Asakdiyah (2007) bahwa semakin tinggi tingkat dividen dibayarkan, maka semakin sedikit laba yang ditahan, sehingga akan menghambat pertumbuhan. Sebaliknya apabila perusahaan menahan sebagian besar pendapatannya, maka semakin besar dana yang tersedia untuk ditanamkan kembali di dalam perusahaan. Hal ini akan mempercepat pertumbuhan perusahaan.

b. Analisis pengaruh Return On Assets (ROA) terhadap Kebijakan Dividen.

Dari uji parsial diperoleh bahwa variabel Return On Assets berpengaruh positif dan signifikan terhadap kebijakan dividen. Hal ini ditunjukkan dengan koefisien thitung sebesar 4,827 dengan nilai signifikansi sebesar 0,000 lebih kecil dibanding dengan taraf tingkat signifikan yang diharapkan yaitu $5 \%(0,000<0,05)$. Hasil tersebut sejalan dengan penelitian Prasetia (2010) bahwa secara statistik ROA mempunyai pengaruh positif dan signifikan terhadap Kebijakan Dividen. Semakin besar ROA maka diharapkan perusahaan akan membagikan dividen yang lebih tinggi kepada para pemegang saham.

c. Analisis pengaruh Shareholder Dispersion (Variance) terhadap Kebijakan Dividen.

Dari uji parsial diperoleh bahwa variabel Shareholder Dispersion (Variance) berpengaruh negatif dan signifikan terhadap kebijakan dividen. Hal ini ditunjukkan dengan koefisien thitung sebesar $-3,420$ dengan nilai signifikansi sebesar 0,002 lebih kecil dibanding dengan taraf tingkat signifikan yang diharapkan yaitu $5 \%(0,002<0,05)$. Hasil tersebut sejalan dengan penelitian Prasetia (2010) bahwa secara statistik Shareholder Dispersion mempunyai pengaruh negatif dan signifikan terhadap Kebijakan Dividen. Shareholder Dispersion berpengaruh negatif dan signifikan karena ketika kepemilikan saham menyebar, maka akan menyebabkan pemegang saham akan sulit mengontrol manajemen dan kemudian menimbulkan konflik keagenan. Untuk mengurangi konflik keagenan tersebut dengan cara meningkatkan rasio pembayaran dividen.

2. Analisis pengaruh Tingkat Pertumbuhan Perusahaan, Return On Assets dan Shareholder Dispersion secara bersama-sama (simultan) terhadap kebijakan dividen.

Dari uji simultan diperoleh bahwa variabel independen Tingkat 
Pertumbuhan Perusahaan, Return On Assets dan Shareholder Dispersion secara bersama-sama (simultan) berpengaruh positif dan signifikan terhadap variabel dependen kebijakan dividen. Hal ini ditunjukkan dengan koefisien $\mathrm{F}$ hitung sebesar 16,089 dengan nilai signifikansi sebesar 0,000 lebih kecil dibanding dengan taraf tingkat signifikan yang diharapkan yaitu $5 \%(0,000<0,05)$. Hasil tersebut sejalan dengan penelitian Rahmawati (2013), bahwa Tingkat Pertumbuhan Perusahaan, Return On Assets dan Shareholder Dispersion secara bersama-sama (simultan) berpengaruh positif dan signifikan terhadap kebijakan dividen.

\section{KESIMPULAN DAN SARAN}

\section{Kesimpulan}

1. Dari hasil Uji $\mathrm{T}$ pengujian hipotesis secara parsial diperoleh hasil bahwa dua variabel Tingkat Pertumbuhan dan Shareholder Dispersion berpengaruh negatif dan signifikan terhadap Kebijakan Dividen. Return On Assets berpengaruh positif dan signifikan terhadap Kebijakan Dividen.

2. Dari hasil analisis uji $\mathrm{F}$ diperoleh hasil bahwa secara bersama-sama (simultan) Tingkat Pertumbuhan Perusahaan, Return On Assets dan Shareholder Dispersion mempunyai pengaruh positif dan signifikan terhadap Kebijakan Dividen pada Industri Manufaktur yang terdaftar di BEI (2011-2013).

\section{Saran}

1. Menambah variabel-variabel lain yang diperkirakan akan berpengaruh terhadap kebijakan dividen, seperti: Debt To Total Asset, Cash Ratio, Size dan Kepemilikan Institusional.
2. Menambah periode pengamatan untuk melihat tingkat konsistensi hasil penelitian.

3. Diharapkan untuk peneliti selanjutnya untuk menambahkan sampel perusahaan dengan menggunakan sampel yang terdaftar di Bursa Efek Indonesia.

\section{DAFTAR PUSTAKA}

Asakdiyah, Salamatun. (2007).

Manajemen Keuangan II: Alat Analisis dan Aplikasi. Universitas Ahmad Dahlan Yogyakarta.

Awat, Napa J. (1999). Manajemen Keuangan: Pendekatan Matematis. Jakarta: Gramedia Utama Pustaka.

Ghozali, Imam. (2005). Aplikasi Analisis Multivariate dengan Program SPSS. Semarang: BPUD.

Prasetia, Indra. (2010). Pengaruh Return On Assets, Shareholder Dispersion dan Tingkat Pertumbuhan Perusahaan terhadap Kebijakan Deviden pada Perusahaan Food and Baverage yang terdaftar di Bursa Efek Indonesia (periode 2004-2008). Skripsi. Universitas Negeri Yogyakarta.

Prastowo, Dwi. (2011). Analisis Laporan Keuangan. Edisi Ketiga. Yogyakarta: UPP STIM YKPN.

Rahmawati, Dita. (2013). Pengaruh Return On Assets (ROA), Shareholder Dispersion dan Tingkat Pertumbuhan Perusahaan Terhadap Kebijakan Deviden Pada Perusahaan Food And Baverage yang Terdaftar di Bursa Efek Indonesia. Skripsi. Universitas Ahmad Dahlan.

Sarjono, Haryadi dan Julianita Winda. (2013). SPSS VS LISRAEL. Jakarta: Salemba Empat. 
Sartono, Agus. (2001). Manajemen Keuangan: Teori dan Aplikasi. Edisi Keempat. Yogyakarta: BPFE.

Sugiyono. (2007). Metode Penelitian Bisnis. Bandung: Alfabeta.

Sundjaja, Ridwan \& Inge, Barlian. (2002). Manajemen Keuangan Dua. Edisi Ketiga. Jakarta : PT Prenhallindo.

Tandelilin, Eduardus. (2010). Portofolio dan Investasi. Edisi Pertama. Yogyakarta: Penerbit Kanisius.

Widarjono, Agus. (2009). Ekonometrika Pengantar dan Aplikasinya. Yogyakarta: Ekonesia. 